\title{
PELATIHAN PEMBUATAN SABUN CUCI TANGAN ANTI BAKTERI BERBASIS ECO ENZYM DARI LIMBAH BUAH-BUAHAN DAN SAYURAN
}

\author{
Retno Setyo Iswati*, Annah Hubaedah, Setiana Andarwulan \\ Prodi Sarjana Kebidanan dan Pendidikan Profesi Bidan \\ Universitas PGRI Adi Buana Surabaya \\ Coresponding author*: retnoiswati@unipasby.ac.id
}

\begin{abstract}
The behavior of washing hands with soap is an important component to break the chain of spread and transmission of the corona virus. Antiseptic hand soap that has been circulating in the market contains chemical disinfectant ingredients as a powerful component to kill various pathogenic microorganisms including the corona virus. Frequent and long-term use of hand soap will have side effects on the skin in the area of use. Eco enzyme is a product in the form of a liquid from the fermentation of organic waste from vegetables and fresh fruits. The content of eco enzyme is acetic acid (H3COOH) which can kill germs, viruses and bacteria. The selection of eco enzyme as the basic ingredient for making hand soap because it utilizes organic kitchen waste from the remnants of vegetables and fruits as well as the content of eco enzyme that can kill germs, viruses and bacteria and is environmentally friendly. This activity aims to increase public knowledge about eco enzymes and create innovative products by utilizing organic waste that functions for health and is environmentally friendly. The training method used is to provide material in lectures, discussions, demonstrations and assistance in making hand soap. The participants of the activity were people from $R W$ 10, Keputran sub-district, Tegalsari sub-district, Surabaya, totaling 20 people. Evaluation was carried out directly at the end of the activity by discussing and seeing the results of hand washing soap production. Eco-enzyme-based hand soap still requires further development, especially as an anticovid hand soap
\end{abstract}

Keywords: Hand soap; Anti-bacterial; Eco enzym

\section{ABSTRAK}

Perilaku mencuci tangan pakai sabun merupakan komponen penting untuk memutus mata rantai penyebaran dan penularan virus corona. Sabun cuci tangan antibakteri yang telah banyak beredar dipasaran mengandung bahan desinfektan kimia sebagai komponen ampuh untuk mematikan berbagai mikroorganisme pathogen termasuk virus corona. Penggunaan sabun cuci tangan yang sering dan dalam jangka waktu lama akan memberikan efek samping pada kulit area pemakaian. Eco enzyme merupakan produk berupa cairan fermentasi sisa dapur berupa sayur dan buah-buahan segar. Kandungan eco enzyme adalah asam asetat $\left(\mathrm{H}_{3} \mathrm{COOH}\right)$ yang dapat membunuh kuman, virus dan bakteri. Pemilihan eco enzyme sebagai bahan dasar pembuatan sabun cuci tangan karena memanfaatkan limbah organic dapur dari sisa-sisa sayuran dan buahbuahan serta kandungan eco enzyme yang dapat membunuh kuman, virus dan bakteri serta ramah lingkungan. Kegiatan ini bertujuan menambah pengetahuan masyarakat tentang eco enzyme dan membuat produk inovatif dengan memanfaatkan limbah organic yang berfungsi untuk kesehatan serta ramah lingkungan. Metode pelatihan yang digunakan adalah dengan memberikan materi secara ceramah, diskusi, demonstrasi dan pendampingan pembuatan sabun cuci tangan. Peserta kegiatan merupakan masyarakat RW 10, kelurahan Keputran, kecamatan Tegalsari Surabaya yang berjumlah 20 orang. Diakhir kegiatan langsung dilakukan evaluasi dengan berdiskusi dan melihat produksi sabun cuci tangan yang sudah dibuat. Sabun cuci tangan berbasis eco enzyme masih memerlukan pengembangan lebih lanjut, khususnya sebagai sabun cuci tangan anti covid

Keywords: Sabun cuci tangan; Anti bakteri; Eco enzym

Copyright (C 2021, Retno Setyo Iswati, Annah Hubaedah, Setiana Andarwulan. This is an open access article under the CC-BY NC-SA license. http:// DOI 10.30656/ps2pm.v3i2.4007

Retno Setyo Iswati, Annah Hubaedah, Setiana Andarwulan, Pelatihan Pembuatan Sabun Cuci Tangan Anti Bakteri Berbasis Eco Enzym dari Limbah Buah-buahan dan Sayuran 


\section{PENDAHULUAN}

Semenjak kasus pertama Covid19 diumumkan pada bulan Maret 2020, Pemerintah terus berupaya melakukan langkah-langkah mitigatif dan penanganan seoptimal mungkin agar virus tidak semakin menyebar dan menekan korban jiwa. Salah satu langkah untuk memutus rantai penularan covid-19 adalah menerapkan perilaku pencegahan Covid-19 dengan 5 M (memakai masker, mencuci tangan pakai sabun, menjaga jarak, menghindari kerumunan dan membatasi mobilitas/interaksi.

Mencuci tangan pakai sabun di air mengalir mencerminkan perilaku hidup bersih dan sehat (PHBS) yang ada di masyarakat. Perilaku mencuci tangan pakai sabun merupakan komponen penting untuk memutus mata rantai penyebaran dan penularan virus corona. Belum diketahui secara pasti kapan pandemi Covid-19 ini berakhir maka diperlukan penerapan perilaku hidup bersih dan sehat secara konsisten dan berkelanjutan (Sultan \& Zikri, 2021).

Mencuci tangan menggunakan sabun setiap selesai kegiatan dapat menjaga kebersihan tangan dari mikroorganisme patogen. Sabun cuci tangan antibakteri yang telah banyak beredar dipasaran mengandung bahan desinfektan kimia sebagai komponen ampuh untuk mematikan berbagai mikroorganisme pathogen termasuk virus corona. Pertahanan pertama dari masuknya mikroorgamisme pathogen ke dalam tubuh adalah kulit, sehingga penggunaan sabun cuci tangan dengan bahan desinfektan kimia yang sering dan dalam jangka waktu lama akan memberikan efek samping pada kulit area pemakaian akan mengalami iritatif. Berdasarkan keadaan tersebut mendorong untuk melakukan pencarian sumber bahan pembuatan sabun cuci tangan antibakteri dari bahan alamiah dan ramah lingkungan Eco enzym merupakan produk berupa cairan dari hasil olahan 
limbah organik sayur dan buahbuahan segar yang difermentasi dengan menggunakan gula merah (Rochyani et al., 2020). Sulaeman dkk melaporkan dalam penelitiannya bahwa kandungan eco enzyme adalah asam asetat $\left(\mathrm{H}_{3} \mathrm{COOH}\right)$ yang dapat membunuh kuman, virus dan bakteri (Sulaeman et al., 2005). Selain itu eco enzyme juga mengandung Lipase, Tripsin, dan Amilase yang mampu mencegah bakteri pathogen. Dalam penelitian lain disebutkan bahwa eco enzyme memiliki kemampuan tinggi dalam membunuh bakteri E. coli, S. aureus, S. Typhi, C. Albicans, dan virus (Aruna \& P, 2015).

Pemilihan eco enzyme sebagai bahan dasar pembuatan sabun cuci tangan karena bahannya yang mudah didapat yaitu dengan memanfaatkan limbah organic dapur dari sisa-sisa sayuran dan buah-buahan serta kandungan eco enzyme yang dapat membunuh kuman, virus dan bakteri. Dengan adanya kegiatan ini masyarakat merasa terbantu untuk memanfaatkan limbah organic yang dapat digunakan sebagai salah satu bahan pembuatan sabun cuci tangan.

\section{METODE PELAKSANAAN}

Waktu dan Tempat

Program Pengabdian Pada Masyarakat dengan tema "Pelatihan Pembuatan Sabun Cuci Tangan Anti Bakteri Berbasis Eco-Enzyme dari Limbah Buah-buahan dan Sayuran" dilakukan oleh tim kegiatan PPM terdiri atas 3 dosen dan 4 mahasiswa Program Studi Sarjana Kebidanan, Universitas PGRI Adi Buana Surabaya. Kegiatan ini dilaksanakan pada tanggal 29 Oktober 2021, dengan sasaran masyarakat di wilayah RW 10, Kelurahan Keputran, Kecamatan Tegalsari, Surabaya.

\section{Persiapan Alat/Bahan}

Persiapan alat dan bahan yang dibutuhkan terdiri dari cairan ecoenzim, texapom, air bersih, EDTA, Nacl, gliserin, wadah plastik, dan pengaduk, serta botol $200 \mathrm{~mL}$ 


\section{Prosedur Pelaksanaan}

Kegiatan PPM menggunakan beberapa tahapan dan mengikuti protokol kesehatan, yaitu :

\section{Pendahuluan}

a. Sebelum pelaksanaan dilakukan rapat koordinasi pembagian kerja tiap sie, mulai dari persiapan tempat kegiatan, peralatan yang dibutuhkan, roundown acara, dan evaluasi yang akan dilakukan.

b. Sie kesekretariatan melakukan pengurusan perizinan lokasi ke Badan Kesatuan Bangsa dan Politik (BAKESBANGPOL) Provinsi Jawa Timur dan Kelurahan Keputran, serta pendistribusian undangan kepada masyarakat RW 10.

\section{Pelaksanaan}

a. Masyarakat RW 10 Kelurahan Keputran Surabaya, yang hadir sebagai peserta kegiatan berjumlah 20 orang

b. Pemberian materi tentang manfaat eco enzyme oleh tim
PPM

c. Pembagian kelompok, persiapan alat dan bahan pembuatan sabun cuci tangan

- Peserta yang berjumlah 20 orang dibagi menjadi 4 kelompok@ 5 orang

- Volume akhir sabun cuci tangan yang dihasilkan berjumlah $\quad 1000 \quad \mathrm{~mL}$ sehingga tiap kelompok mendapatkan $800 \mathrm{~mL}$ air bersih dan $200 \mathrm{~mL}$ ecoenzyme

d. Pembuatan sabun cuci tangan, dengan cara :

- Menuangkan $800 \mathrm{~mL}$ air bersih ke wadah plastik

- Masukkan texapom 100 gram ke air bersih, dan aduk hingga larut dan tidak berbusa

- Campurkan EDTA 5 gram ke dalam larutan, kemudian tambahkan gliserin 10 gram, aduk hingga merata 
- Masukkan 100 gram Nacl aduk terus hingga mengental

- Masukkan $200 \mathrm{~mL}$ cairan eco enzim, aduk hingga merata

e. Pengemasan produk dengan cara : botol $200 \mathrm{~mL}$ yang sudah disiapkan diberi label, kemudian dimasukkan cairan sabun cuci tangan yang sudah dihasilkan.

\section{Evaluasi Kegiatan}

Diakhir kegiatan langsung dilakukan evaluasi dengan berdiskusi dan melihat produksi sabun cuci tangan yang sudah dibuat, dilanjutkan berdiskusi terkait proses pembuatan sabun cuci tangan.

\section{HASIL DAN PEMBAHASAN}

Pemberian Materi

Kegiatan Pengabdian Pada Masyarakat dilakukan secara luring, dimulai dengan pemberian materi tentang pencegahan penyebaran Covid-10 dengan protokol kesehatan salah satunya adalah mencuci tangan menggunakan sabun, serta tentang eco enzyme beserta manfaatnya. Pemberian materi dengan metode ceramah tanya jawab diberikan oleh dosen Program Studi Sarjana Kebidanan Universitas PGRI Adi Buana Surabaya. Peserta sangat antusias dengan pemberian materi tersebut ditandai dengan banyaknya pertanyaan yang diberikan kepada pemateri. 


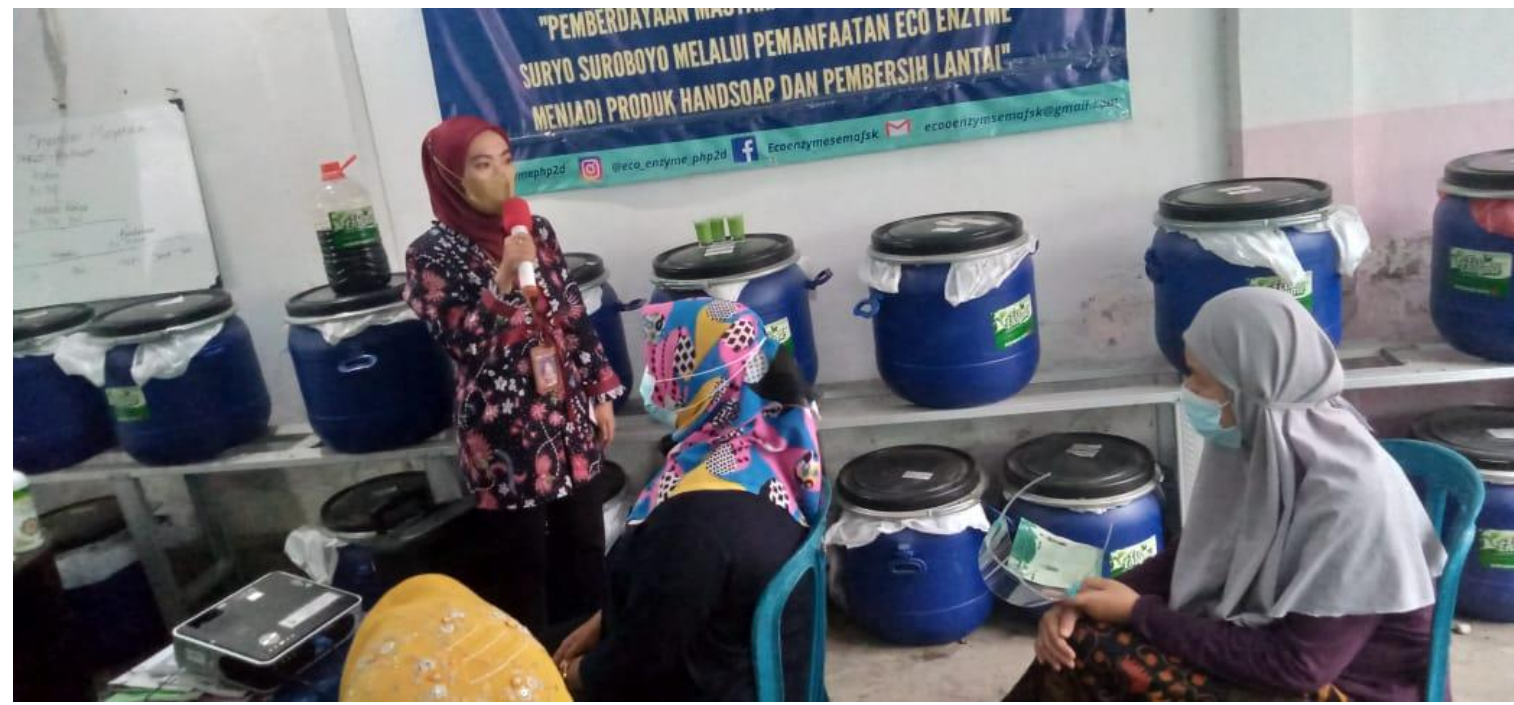

Gambar 1. Tim memberikan materi tentang eco enzyme dan manfaatnya

Sumber: Tim Pengabdian Masyarakat Prodi Sarjana Kebidanan dan Pendidikan Profesi Bidan Universitas PGRI Adi Buana Surabaya

\section{Pelatihan Pembuatan Sabun Cuci}

Tangan

Kegiatan pelatihan dimulai dengan membagi peserta menjadi 4 kelompok, masing - masing kelompok terdiri atas 5 peserta. Setiap kelompok mendapatkan alat dan bahan pembuatan sabun cuci tangan, yang terdiri dari : cairan eco enzyme berusia 3 bulan sebanyak $200 \mathrm{~mL}$, air bersih $800 \mathrm{~mL}$, texapom 100 gram, gliserin 10 mL, EDTA 5 gram, Nacl 100 gram, 1 wadah plastik, 1 batang pengaduk, dan 5 botol kosong $200 \mathrm{~mL}$ untuk tempat produk sabun cuci tangan yang sudah jadi.

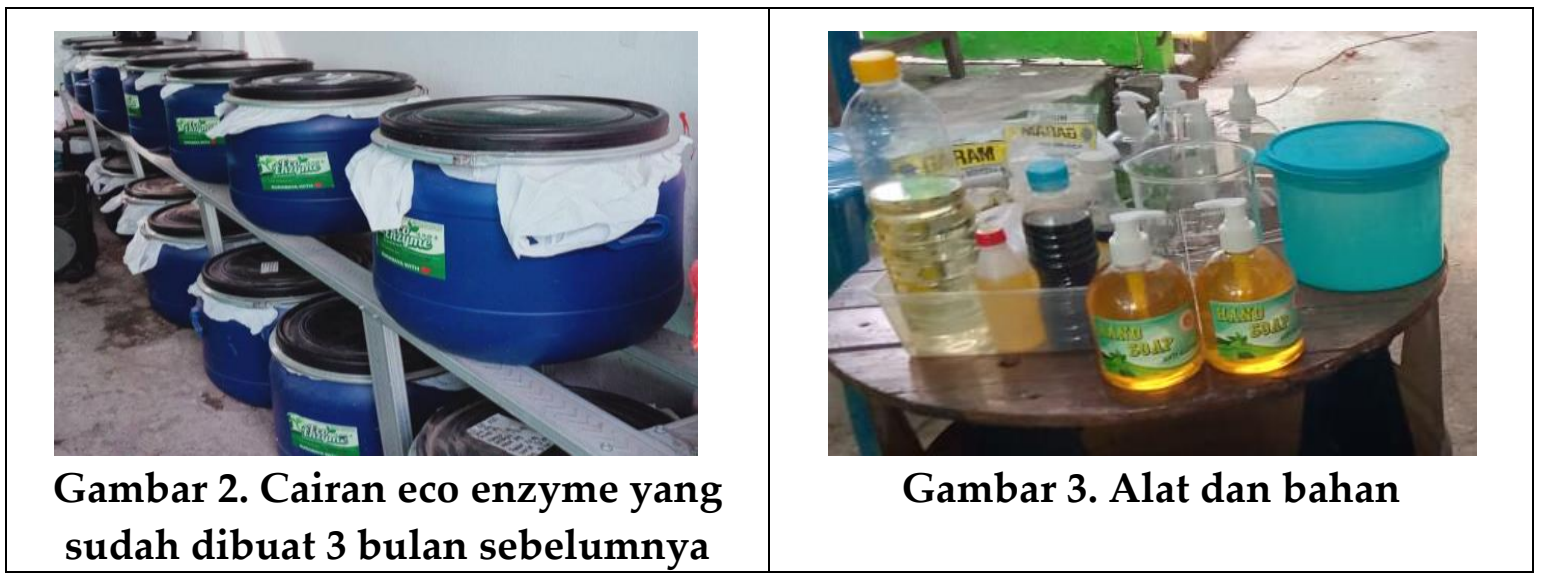

Retno Setyo Iswati, Annah Hubaedah, Setiana Andarwulan, Pelatihan Pembuatan Sabun Cuci Tangan Anti Bakteri Berbasis Eco Enzym dari Limbah Buah-buahan dan Sayuran 


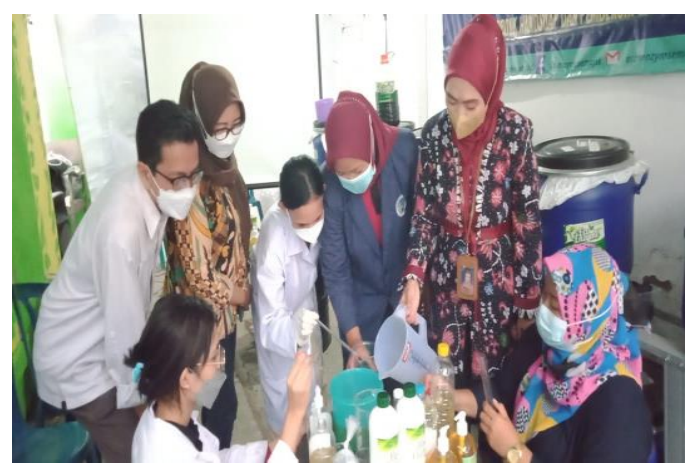

Gambar 4. Pendampingan pembuatan sabun cuci tangan

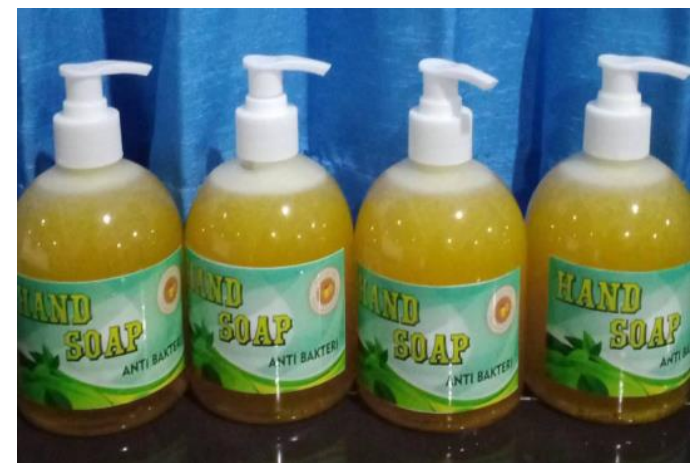

Gambar 5. Produk sabun cuci tangan yang dihasilkan dari kegiatan PPM
Pembuatan sabun cuci tangan berbasis eco enzyme menggunakan formula perbandingan $10 \%$ eco enzyme: $40 \%$ air bersih. Volume akhir dari pembuatan sabun cuci tangan adalah $1000 \mathrm{~mL}$, sehingga masingmasing kelompok harus mencampur sesuai perbandingan yaitu ecoenzyme $200 \mathrm{~mL}$ dan air bersih $800 \mathrm{~mL}$. Wadah plastik sebagai tempat untuk mencampur semua bahan, dan diaduk hingga larut. Agar kulit tidak terasa kering diberikan penambahan gliserin, sedangkan kentalan larutan sabun dibuat dengan menambahkan Nacl sesuai takaran. Pengadukan dilakukan secara continue agar larutan menjadi homogen, selanjutnya larutan sabun cuci tangan yang sudah jadi dikemas dalam botol $200 \mathrm{~mL}$ dan diberi label

Perilaku mencuci tangan pakai sabun merupakan salah satu cara mencegah menyebaran virus corona. Mencuci tangan pakai sabun merupakan penerapan perilaku hidup bersih dan sehat yang penting dilakukan secara berkelanjutan, karena belum dketahui secara pasti akhir dari pandemi Covid-19. Sabun cuci tangan antibakteri yang banyak beredar dipasaran mengandung bahan desinfektan kimia yang bila sering digunakan dan dalam jangka waktu lama akan memberikan efek samping pada kulit. 
Limbah organik sayur dan buah merupakan bahan yang mudah didapat untuk dijadikan eco enzyme. Larutan eco enzyme merupakan fermentasi dari limbah organik, gula merah dan air bersih. Sulaeman dkk (2005) melaporkan dalam penelitiannya bahwa kandungan eco enzyme adalah asam asetat $\left(\mathrm{H}_{3} \mathrm{COOH}\right)$ yang dapat membunuh kuman, virus dan bakteri (Sulaeman et al., 2005 ). Selain itu eco enzyme juga mengandung Lipase, Tripsin, dan Amilase yang mampu mencegah bakteri pathogen. Dalam penelitian lain disebutkan bahwa eco enzyme memiliki kemampuan tinggi dalam membunuh bakteri E. coli, S. aureus, S. Typhi, C. Albicans, dan virus (Aruna \& P, 2015).. Aktivitas antibakteri pada larutan eco enzyme didapat selama proses fermentasi yang menghasilkan alkohol dan asam organuk. Apabila kandungan asam organik tinggi pada larutan enzim maka derajat keasaman juga semakin rendah. Pembuatan eco enzim disebut berhasil jika didapatkan derajat keasaman $(\mathrm{pH})$ yang rendah yaitu $<4$, dengan aroma buah yang wangi dan segar (Safitri et al., 2021). Dalam penelitian lain disebutkan bahwa $\mathrm{pH}$ 6,8 dengan koefisien fenol setara 1:4 dapat membunuh bakteri pathogen (Dina et al., 2021)

\section{SIMPULAN}

Kegiatan Pengabdian Pada Masyarakat di RW 10, Kelurahan Keputran, Kecamatan Tegalsari Surabaya telah dilaksanakan dengan sukses. Tahapan pelaksanaan kegiatan yang terdiri dari pemberian materi dengan metode ceramah, diskusi, demonstrasi serta pendampingan pembuatan sabun cuci tangan oleh tiap kelompok, menambah pengetahuan masyarakat tentang manfaat eco enzyme, melatih ketrampilan masyarakat dalam pembuatan sabun cuci tangan, dan masyarakat dapat menggunakan sabun cuci tangan yang sudah dibuatkan dalam kehidupan sehari- 
hari. Produk sabun cuci tangan yang dibuat dalam kegiatan ini belum dikomersialkan tetapi dapat digunakan sehari-hari oleh individu dan keluarga. Sabun cuci tangan berbasis eco enzyme masih memerlukan pengembangan lebih lanjut, khususnya sebagai sabun cuci tangan anti covid

\section{UCAPAN TERIMAKASIH}

Terima kasih kepada masyarakat RW 10, Kelurahan Keputran, Kecamatan Tegalsari Surabaya yang telah memberikan kesempatan untuk melakukan kegiatan Program Pengabdian Masyarakat

\section{REFERENSI}

Aruna, C., \& P, S. (2015). Solubilisation of Waste Activated Sludge Using Garbage 3 Enzyme Produced From Different PreConsumer Organic Waste. RSC Advances, 5, 51421-51427.

Dina, Y. O., Azmi, A. A., Muryaningsih, I., Cholily, H. V., Pratama, K. R., \& Silviana, S. (2021). Organic Waste Enzyme Protect Covid-19 Sebagai Produk
Sanitasi ekonomis dan ramah lingkungan dengan inovasi percepatan eco_fermento. 3(2), 0-5.

Rochyani, N., Utpalasari, R. L., \& Dahliana, I. (2020). Analisis Hasil Konversi Eco Enzyme Menggunakan Nenas (Ananas Comosus ) Dan Pepaya (Carica papaya L.). 5(2), 135-140.

Safitri, I., Yuliono, A., Sofiana, M. S. J., Helena, S., Kushadiwijayanto, A. A., \& Warsidah, W. (2021). Peningkatan Kesehatan Masyarakat Teluk Batang secara Mandiri melalui pembuatan Handsanitizer dan Desinfektan berbasis Eco-Enzyme dari Limbah Sayuran dan Buah. Journal of Community Engagement in Health, 4(2), 371-377. https://doi.org/10.30994/jceh.v4i2 .248

Sulaeman, Suparto, \& Eviati. (2005). Petunjuk Teknik Analisis Kimia Tanah, Tanaman, dan Pupuk.

Sultan, M., \& Zikri, L. O. K. (2021). Membiasakan Cuci Tangan Pakai Sabun Pada Masyarakat Saat Pandemi COVID-19 di Kompleks Perumahan Kota Samarinda. Jurnal Abdimas BSI: Jurnal Pengabdian Kepada Masyarakat, 4(2), 279-286. https://ejournal. bsi.ac.id/ejurnal/index.php/abdi mas/article/view/10417 